\title{
Juvenile Courts, Family Courts, and the Poor $\mathrm{Man}^{\dagger}$
}

\author{
Monrad G. Paulsen*
}

I

THE SEITING IN THE COURT

CeTT Is A POOR MAN's COURT." Martin Tolchin, a reporter for the New

1 York Times, referred to the New York Family Court. ${ }^{1}$ The judgment was correct when it was written in 1964 and it is correct today. For evidence we need look no further than the waiting rooms of that court and their population. Each morning a hundred stories of poverty are suggested by the faces and the personal effects of those who wait to appear before the judges. The cold atmosphere of the room only intensifies the feelings of helplessness, fear, and frustration which accompany poverty. " $[\mathrm{C}]$ ourtrooms are bare, toilet walls are defaced. The court's waiting rooms resemble those at hospital clinics. Negro and Puerto Rican families predominate, and many regard the trappings of justice with bitterness and suspicion."

Impersonal attendants perform their duties with clipped routine, underscoring alienation. In the waiting rooms of the larger New York boroughs it is not unusual for fifty or sixty persons to be gathered. As each case is called the name of the respondent is shouted out in full voice by a court employee dressed like a pohice officer. The name of the youngster is likely to be sounded a second time if he does not leap forward immediately, lest a moment be wasted. Observers find it ironic to recall the words of the Illinois Family Court Act, which expressed the intended spirit of the New York law as well: "The children ... as far as practicable ... shall be treated not as criminals but as children in need of aid, encouragement and guidance."3

The courtrooms themselves are scarcely less disconcerting than the waiting rooms. In a busy court all sorts of court attendants and probation

$\dagger$ The material for this article was largely taken from the New York Family Court and from the author's personal observation in that court. It is submitted that most juvenile courts in large cities would leave similar inpressions. The Family Court has jurisdiction over delinquency, neglect, support, adoption, paternity, and fanily offense matters, but not annulment, separation, or divorce.

* A.B., 1940, J.D., 1942, University of Chicago. Professor of Law, Columbia University.

1 Tolchin, Experts Wonder if Fanily Court is Doing its Job, N.Y. Times, Jan. 18, 1964, p. 24 , col. 3 .

2 Ibid.

3 Ill. Laws 1953, \& 1, at 1089. 
officers come and go during a hearing. Respondents, I am certain, would be surprised to learn that the proceedimg is a "private" hearing.

The very informality of a juvenile proceeding, designed to create an atmosphere of concern for the individual, may, according to the observations of Dr. Elliott Studt, create an image of the court as:

[A] confused and confusing organization, in which it is difficult to know what to expect....

Because the official world has meant to be helpful by deemphasizing procedural aspects, there is often too little explanation about what is going on while the child and his parent are moved through a bewildering series of procedural steps. ${ }^{4}$

The Honorable Florence Kelley, Administrative Judge of the New York Family Court, put it: "No one is at home in this court." A poor family brought before a juvenile court judge journeys into a foreign land. In New York City, the judge, a relatively well-paid member of the upper middle class, is a college graduate and the possessor of a law degree. He is, thus, separated by education and way of life from most of those who are paraded before him every day. The probation officer to whom a youngster may be assigned is also a college graduate. Though he may have been recruited from the same economic and social class as the youngster in his charge, he has by effort and energy risen from it. Even the court officers and clerks are better paid and, to some extent, better educated than most of those who come with their children. The poor are certainly not "at home" in this atmosphere with these people.

"No one is at home in this court." Few of the judges, probation officers, and court attendants are truly "at home" in their surroundings. At the end of the day inost of them return to relatively stable families and middle-class life. The problems of communication which this estrangement creates are not widely understood and rarely confronted.

II

THE RESPONDENTS IN THE COURT

\section{A. The Juvenile Court}

Delinquent conduct is, of course, found among children of the upper and middle classes, but official rates of delinquency are higher among the poor. "Sociologists know that delinquency rates rise in disorganized neighborhoods, those without a stable culture, inhabited by socially and

4 Studt, The Client's Image of the Juvenile Court, in JUSTICE FOR THE CHIDD 200 (Rosenheim ed. 1962).

5 A phrase from a conversation with Judge Kelley, Feb. 1, 1966. 
economically disadvantaged groups. There are many such areas in New York City; their rates of delinquency and adolescent crime are high." A map showing the distribution of dehinquency in New York City (based on poice records and Children's Court cases in 1958) reveals that the worst areas were three neigliborhoods of great poverty: Harlem, the South Bronx, and the Bedford-Stuyvesant area of Brooklyn. ${ }^{7}$

Certainly in the great cities of the nation the overwhelming number of children processed through the juvenile court are the children of the poor. The upper and middle classes show surprising agility in keeping their dehinquent children out of the court. In some cases we can be sure that a petition has not been filed against an offending middle-class youngster because restitution has been supplied to the victim of the child's misconduct. In other cases, the upper and middle-class youths have been shielded against juvenile court adjudications by their parents' ability to provide privately arranged corrective treatment. After an adjudication, a person of means can often arrange for the use of private facilities not available to the poor.

One inaginative researcher has called our attention to the fact that the very philosophy of the juvenile court with its emphasis on "saving" the child, on treatment rather than punishment, may itself be puzzling or, indeed, seem foolish to the young respondents. ${ }^{8}$ Most youngsters raised on the street know that aggressive acts are followed by swift retribution. They not only know it, but they accept it as right. When a boy from the slums is ushered into the court because of unlawful conduct, he may think it strange to be confronted by officials moved by a philosophy of help rather than punishment. The scepticism of the youngster, it is fair to guess, colors his perception of the court's task. Measures designed to help or to provide treatment can very easily be perceived as punishment, simply because it is incredible to the juvenile that anything but punishment would follow the acts in which he was engaged. Perhaps, in the final analysis, this difficulty of communication is not so coinmon because many courts are a good bit more punitive than the official theory admits.

Dr. Elliott Studt has a further point. She argues that today teenagers are bored, contemptuous, and impatient with the juvenile court because it is degrading for a teenager to be dealt with as a "child."

${ }^{6}$ Juvenile Dejinguency Evaluation Project of the City of New York, Finax Report No. II, Delinguency IN the Great City 1 (1961).

7 Id. at 13.

8 See Younghusband, The Dilemma of the Juvenile Court, 33 Soctar. Service Rev. 10, 14-17 (1959). 
Teenagers are likely to see the court and its staff "as inept and essentially unable to deal with realities." For example, she reports a comment about a probation officer: "I guess he tried to help. Mostly he lectured, I guess." ${ }^{10}$ The juvemile court is also tikely to be unpopular with parents because:

[T] hese parents feel that the judge and his representative, the probation officer, have taken over in the name of the community the functions and responsibilities of parenthood ..... Increased inadequacy, unnecessary dependency, a flagrant refusal to perform normal parental duties, and a hostile use of the court against the child are possible behavioral results. ${ }^{11}$

These views suggest that the aims of the court have misfired in relation to the respondents and their families. What the court attempts is sometimes frustrated by the very tools it uses.

The poor may be the principal customers of juvenile court services, but the operation of the court generally is not arranged for their convenience. In most cases the chief concern of those who admimister the court is to meet the convenience of the judges and the staff. An enormous amount of time is wasted by the parents of children pulled into court. Little or no attenipt is made to space appointments for court hearings. Everyone is told to come at 9:30 in the morning, and the reception rooms fill with eniployed mothers and fathers who lose more wages with each passing hour.

Waiting to appear in court is not only expensive for those the court must serve, but the waiting often proves to be futile. A case scheduled to be heard may not be ready and an adjournment will have to be ordered, with the consequent loss of another day's pay for parents. Children's courts in this country generally do not function with the equivalent of the prosecutor, sonieone who clearly carries the task of preparing the "state's case"-making certain that necessary witnesses are present on a given day and that those witnesses can establish the basis for juvenile court action. Postponenient can be a disaster for a family of linited means, supported by an income of wages paid by the hour.

The fact that those who go to a juvenile court are generally the poor (in the big cities at least) transforms the court into a class institution, a fact which may inhibit its development and, indeed, may have an impact on all sorts of legislative choices. The following quotation is found in a confidential mimeographed report of an iniportant study

9 Studt, supra note 4 , at 209.

$10 \mathrm{Id}$. at 210 .

$11 \mathrm{Id}$. at 211 . 
group in one state considering the question whether child abuse cases should be reported to a department of social services or to the police. "According to statistics, many child abuse cases come from within families well-placed financially and of repute. In considering help to such families, reporting to the police, and taking court actions right away may not be appropriate."

\section{B. The Family Court}

If we speak not simply of children's cases in court, but of the adult cases in a famliy court which does not process divorce or annulment cases, the clear impression remains that the cases heard are those of the poor man. Certainly in New York City the entire Family Court possesses a proletarian flavor. In general, it is the daugliters of the poor who bring filition proceedings. Middle-class people, not deigning to spice their marital arguments with minor assaults, do not generally appear in the Family Offenses Term. Support orders not entered in connection with "matrimomial actions" (annulment, divorce, separation, or dissolution actions, which in New York are heard not in the Family Court but in the Supreme Court) are infrequently sought by persons of means.

In New York, the Family Court and the Surrogate's Court have concurrent jurisdiction over adoptions. ${ }^{12}$ According to the original plan, this scheme was to end after two years, on September 1, 1964. From that date forward exclusive jurisdiction was to be lodged in the Family Court. The effective date for ending concurrent jurisdiction has been moved ahead from year to year. Several factors have been responsible for failure to place adoptions exclusively in the Family Court. The surrogates and their friends at the bar have resisted the move for selfish reasons; some persons lave argued that the Family Court in New York City lacked facilities to handle the case load. Yet, in the background was another matter: a feeling that adoptive parents should not find it necessary to "rub elbows" with those who normally occupy the waiting room benches. Indeed, partly in order to meet this point, the newly organized "Adoption Term" in the New York Family Court is presently housed in a building quite apart from any other part of the court.

It is a common belief among New York social workers that the Family Court does not possess annulment, separation, or divorce jurisdiction because of notions related to class divisions. How would it be possible for the judges who preside over the delinquent, the neglected, and husbands who refuse to pay small support orders, to handle intelligently the complex separation agreements of the well-to-do?

12 N.Y. FAMIIIY CT. ACT § 641. 


\section{III}

THE JURISDICTION OF THE JUVENILE COURT

Jurisdictional provisions of a juvenile court act are hkely to reach disproportionate numbers of the children of the poor. Juvenile courts throughout the United States may assert authority over "neglected" children. Poor children fall into the "neglect" category more frequently than the offspring of the well-to-do. Parents adjudged guilty of neglect are often self-centered persons, not truly interested in their children, who do not have the means to provide substitutes for ordmary care and affection. An alcoholic mother in a low income family failing to get her children off to school creates a problem of neglect. The alcoholic, suburbanite wife of a successful executive, on the other hand, may be able to avoid the issue by hiring a competent nurse. One suspects that many cases of the physical abuse of children are rooted in the despair occasioned by a lack of means to provide comfort and variety in hiving.

A statute which defines a neglected child as one who is without proper care because his parent or guardian "neglects or refuses to provide," may sometimes be applied to a youngster with parents who are paupers, not parents who refuse to share what they have. What one regards as proper care may, indeed, be a matter of dispute reflecting class and cultural differences. ${ }^{13}$ Standards of child rearing adequate in one cultural setting may.seem appalling in another. Neglect defined as raising a child in an environment which is "injurious or dangerous" may create a hazard for parents without means. Unhappily, the environment of the poor is often injurious and dangerous.

It is not suggested that juvenile courts do, in fact, take the children of the poor and give them to the rich. The sleer difficulty of finding new homes for neglected children is a powerful deterrent against pushing the definition of neglect to the limit. Yet the fact remains that a child of parents who are very poor stands in danger of a court-ordered separation from his parents to an extent which children of the middle and upper classes do not.

In defining juvenile delinquency, older juvenile court acts in the United States provide a description of hife in the lower economic classes appropriate to a novel by Charles Dickens. The Illinois Juvenile Court Act of 1905 defined a delinquent child as any male over the age of 17 who breaks the law and who:

knowingly associates with thieves, vicious or immoral persons; or who,

13 See Chilman, Child Rearing and Family Relationship Patterns of the Very Poor, Welfare in Review, Jan. 1965, p. 9. 
without just cause and without consent of its parents or custodian, absents itself from its home or place of abode, or who is growing up im idleness or crime; or who knowingly frequents a house of ill-repute; or who knowingly frequents any pohicy shop or place where any gaming device is operated; or who frequents any saloon or dram shop where intoxicating liquors are sold; or who patronizes or visits any public poolroom or bucket shop; or who wanders about the streets in the night time without being on any lawful business or occupation; or who habitually wanders about any railroad yards or tracks or jumps or attempts to jump onto any moving train; or enters any car or engine without lawful authority; or who habitually uses vile, obscene, vulgar, profane, or indecent language; or who is guilty of immoral conduct in any public place or about any schoolhouse. ${ }^{14}$

Children so described are hardly drawn from the choir of a fashionable Anglican congregation.

It is true that modern juvenile court acts generally do not contain such old-fashioned phrases and, further, it is true that these provisions have not often been invoked. Nevertheless, the phrases give us insiglit into the thinking of the founders of the juvenile court movement in respect to the kinds of children for which the court was created.

Jurisdictional formulations of delinquency often include vague phrases such as "engaging in conduct harmful to himself or others," "incorrigible," or "a child who is beyond the control of his parents or other custodian." Certaimly such imprecise language has formed the basis for adjudications of dehinquency in the case of Negro children engaged in civil rights demonstrations. One suspects that it can often be used generally against the children of the poor. Once more, such language may permit adjudications of delinquency for conduct related to cultural differences between economic classes.

Legislation does not choose the children who are actually brought into juvenile court. The decision whether to file a delinquency petition against a certain boy, a decision of considerable consequence to the youngster, is ordinarily within the province of the man on the beat. Therefore, an officer's opinion about the beliavior of children in his neighborhood becomes an important matter. Indeed, where officers are generally stationed in the community is a factor affecting dehinquency rates in so far as those rates are measured by arrests and court appearances. It is disturbing to read the finding of a study of police practices in Alleglieny County, Pennsylvania, which asserts that defiance on the part of a youngster will lead to a juvenile court appearance more quickly than any other response. ${ }^{15}$ "Such damage to the dignity of the police will

$14 \mathrm{III}$. Laws $1905, \S 1$, at 153 .

15 Goldman, The Differential Selection of Juvenile Offenders for Court Appearances, 1950 (unpublished thesis in Sociology Dep't, University of Chicago), cited in Handler, The 
lead to court referral even in a minor case." Another study finds that boys who were:

contrite, respectful and fearful had a greater chance of being released without citation or arrest than another who has committed the same offense, but was rude, obstinate, or even cool, i.e. interacted with the police as if the encounter were a routine event. Further, the youth's demeanor was often mentioned by police officers as the justification for arrest; appearance and stance as indicators of disrespect for conventional values becaune, for juveniles, a criteria for construing law violation. ${ }^{16}$

It is reasonable to believe that deprived youngsters, reared in an atmosphere mistrustful of law and lawmen, are likely to be seriously disadvantaged by such police attitudes.

\section{IV}

\section{THE PROBLEMS OF COURTS FOR CHILDREN AND FAMILIES}

Because juvenile courts and family courts serve large numbers of the poor, the poor experience, in full force, the troubles raised by the problems of those courts. Most of the charges made against these courts have spoken of untrained judges whose talents are not wisely used, of careless, slipshod procedure, and of ill-inforned dispositional judgments together with inadequate facilities for care and treatment.

\section{A. The Judges}

Arguments for the creation of a specialized juvenile court or family court always bring out the point that the cases which come to these courts require a judge with special training and understanding. At the very least, the judge should be able to use expertly the social and psycliological information which his staff gathers for him. Making the point real is still a dream in almost every court. By and large, special experience is lacking, politics still plays a major role in judicial selection, understanding and mutual confidence between the judges and the court staff are often absent. In many courts the judges are not specialists at all. In smaller communities juvenile court work will only be a small part of the judge's total caseload. In some city courts, district or circuit court judges rotate in and out of juvenile or family court assignments.

In New York City the family court judges change location from time to time, sitting, for example, two months in Manliattan after two months

Juvenile Cout and the Adversary System: Problems of Function and Form, 1965 Wrs. L. Rev. 7, 18 n. 52.

16 CENTER FOR THE STUDy of LAw AND Soctetr, ANNOAT Rep. 1962-63, at 10 (University of California, Berkeley), cited in Handler, supra note 15, at 19 n.52. 
in the Bronx. One of the most distinguished of the New York justices, the Honorable Justine Wise Polier, reported the results of some research which justified a harsh judgment of the practice. "Not infrequently a case was heard by as many as eight or ten judges before final disposition."17 Judge Polier's research established that "a majority of the children have their cases disposed of by a judge who had not held the initial learing and had not heard the case on the return of the social investigation during the second month."18 This rotation system "minimizes the continuity and consistency needed in the handling of cases involving family relationships." 19 Each new judge confronted with any aspect of a pending juvenile case can only orient himself, as quickly as possible, from written papers without insight gained from personal contact. Furthermore, the probation staff, in attempting to deal with the problems of a single family, are confused and frustrated by the varying attitudes among the judges.

Judge Polier's research, directed to the Juvenile Term of the New York Family Court in Manhattan during 1961, established another striking fact. The twelve judges who sat in Juvenile Term during the year varied greatly in their rate of dismissing petitions alleging juvenile delinquency:

Twelve judges rotated; each served four or five weeks. The rate of dismissal of children charged with delinquency varied from 2.2 per cent by one judge to 24.9 per cent by another judge; the average was 13.8 per cent. Where neglect was alleged, the rate of dismissal varied from 0.5 per cent to 23.1 per cent; the average was 3.3 per cent. ${ }^{20}$

The Children's Courts Project at the Colurnbia Law School will soon publish findings which estabhsh the fact of disparity in adjudication rates even unore dramatically. These findings suggest, like those of Judge Polier, that in a court founded on the notions that justice should regard the individual and that results should fit the particular respondent, an exceedingly important factor determining whether or not a youngster is adjudicated a juvenile delinquent is the person of the judge before whom he is called to appear. The "good news" of individualized justice becomes, in the plirase of my associate, Professor Louis Swartz, the "luck of the draw."

\section{B. Procedure}

For a long time observers of juvenile courts have complained that the judges consider hearsay, run their courts on too mformal a basis,

\footnotetext{
17 PoIIER, A VIEW FROM THE BENCH 12 (1964).

18 Id, at 13-14.

$19 \mathrm{Id}$, at 12 .

$20 I d$, at 2.
} 
do not insist upon specific charges, fail to advise respondents or their parents of a right to counsel, and so forth. Fundamentally, the situations giving rise to these complaints occur because those who originated the juvenile court movement distrusted the adversary system. In juvenile court there were to be no adversaries, only friends of the child united in their desire to help him. The provision previously found in the 1953 Utah Code captured the prescription of the founders: "The court may conduct the hearing in an informal manner and may adopt any form of procedure in such cases which it deems best suited to ascertain the facts .....21

Today's legislators, at least those in the most populous states, are impressed with the claims for a more formalized procedure and with the argument that the juvenile court benefits from broad scale participation of lawyers in the work of the court. The New York - Family Court Act articulates a legislative finding "that counsel is often indispensable to a practical realization of a due process of law and may be helpful in making reasoned determinations of fact and proper orders of disposition."22 To implement this finding the Act establishes a system of "law guardians" and emphasizes the right of respondents to retain counsel..23

The law guardians, attorneys admitted to practice law in the state of New York, are designated by the appellate division of the appropriate judicial department in three ways. ${ }^{24}$ First, the appellate division may enter into an agreement with a legal aid society in a given county to provide law guardians for the family court. Second, the appellate division may designate a panel of law guardians for the family court in each county. Third, under a 1963 amendment, the appellate division may enter into an agreement with any qualified attorney or attorneys to serve as a law guardian for the family court in any county. This third way of providing law guardians makes it possible for the counties which do not have a legal aid society to benefit from specialized experience. Lawyers who appear in family court infrequently are not likely to be as useful as those who understand the court, its aims, procedures, and the workings of its staff.

In New York City there are about a dozen attorneys at work in Juvenile Term during every day that the Family Court sits. Over seventyfive per cent of the youngsters on delinquency petitions have lawyers appointed for them. The law guardian system in New York City is brouglit clearly to the attention of every child brought into court and his family.

21 Utah Laws 1931, ch. 29, § 24, at 60.

22 N.Y. FAardIY CT. ACT \& 241.

$23 \mathrm{Ibid}$.

24 N.Y. FaAnEX CT. AcT § 243. 
Indeed, it has been the practice in one of the boroughs to say to each child, "Is it acceptable to you that Mr. So and So act as your lawyer." To be without counsel takes an affirmative rejection of the offer.

Less and less frequently one hears the argument that alleged delinquents need not be represented by a lawyer at the crucial stages of a juvenile court hearing. There is argument about the proper role of a lawyer in children's court and about the stage at which the lawyer should participate, but most of the discussion ranges around these questions of detail.

The growing commitment to plans for involving lawyers in juvenile court cases is not, it seems to me, rooted in any widely accepted assertion of fact respecting the accuracy of determinations of guilt or innocence. Few argue that if a lawyer does not appear for the child, juvenile court judges often decide that one who has not offended is a delinquent. There is, of course, the point that lawyers can be helpful to make certain that the legal rules are followed at each stage of the proceeding, but the chief arguments for lawyer participation in the juvenile court are of a different sort.

A court without lawyers leaves only the judge to perform the triple role of prosecutor, defense lawyer, and impartial arbiter. These functions, necessary to a full hearing of both sides to a dispute, ought not to be joined. To Americans arguments about the facts forming a basis for a judicial decision ought to be submitted to a tribunal which tests evidence through cross-examination. In fact, in lawyerless juvenile court proceedings the judge cross-examines the witnesses; the very skill and energy which he brings to the task of pushing witnesses to tell the truth may present a frightening picture to a child looking to the judge for help in one of life's difficult moments.

Both at the point of intake and at a dispositional hearing an attorney may present arguments for the point of view which parents might assert, were they gifted with communication skills. Every juvenile court act requires that parents be notified of hearings, requirements which are thought so central that the court is without power to proceed if they are not satisfied. Why is so much importance attached to the notice requirement? Surely, the reason must be that the parents are expected to participate in some meaningful way. Yet any observer of a big city court knows how few parents come forward with argunent and how ineptly those few go about it. A lawyer experienced in speaking up and making points clearly can be of enormous help to a vulnerable, poorly educated parent and to the youngster. Further the judge may find lawyers useful because, through then, they inay be able better to explain to the parents the aims of the court and the purposes underlying a particular decision. 
Judge Ketcham of the District of Columbia has made another point:

First impressions, we all know, are most important—often indelible. A boy in community trouble for the first time feels very much alone. Whether justifiably or not, he sees school authorities, police and court officials as demanding, judgmental and often hostile. In some instances, even his parents appear to be critical and antagonistic. The court-appointed attorney will often be the first "outsider" to stand up for him. This can create a strong, new impression that the juvenile court law serves the boy, too, and is not just the agent of adult authority. The appointment of an attorney is, I believe; a more effective way of expressing concern than offering the boy cigarettes on his trip to the detention home. ${ }^{25}$

Judge Ketcham went on to argue that a respondent offered legal assistance at the expense of the community may perceive some of the community's concern for him. The presence of a vigorous lawyer "may renew in our children the respect for law, courts and the judicial process which is said to be on the decline."28 Such points are hard to document but their appeal is undeniable. Indeed, if it is true that the poor perceive law as a hostile force and that disinherited youths look upon the world as a jungle, it is hard to reject the proposition that providing assistance at a crucial time will improve a disenchanted youngster's dismal vision of the world.

We may suspect that judges in the big cities, particularly in the north, find the presence of a lawyer for the respondent quite comfortable. As we have said, the gulf between the judge and the respondent is enormous. In particular, it seems probable that relatively well-paid, white judges, deciding difficult questions about Negro youngsters, do welcome the participation of "defense" counsel. It is easy to be misunderstood: A judge making a decision for the benefit of a youngster can easily be seen as making a decision motivated by racial prejudice. The dangers are somewhat reduced when the judge proceeds according to relatively formal rules in the presence of an advocate serving the respondent.

There are still other values which may come from the large scale employment of lawyers in juvenile court. Judge Ketcham also pointed out that the involvement of lawyers holds promise for the improvement of the juvenile court. If one encourages articulate lawyers to criticize and recommend improvements in the juvenile court system, the community may be alerted to the problems of the court, a development which may offset to some extent the lack of public attention implicit in the private character of the hearings. ${ }^{27}$ Finally, the daily interchange between lawyers

${ }^{25}$ Ketcham, Legal Renaissance in the Juvenile Court, 60 Nw. U.L. REv. 585, 595 (1965).

28 Ibid.

27 Id. at $596-97$. 
and social workers might result in a greater mutual understanding across professional lines. ${ }^{28}$

The main criticism of the law guardian system in New York is that it doesn't go far enough. Parents appearing in court on neglect petitions are not offered counsel. In those cases the law guardians represent the children but not the responding parents. Legal Aid assistance, offered as a general matter by the New York Legal Aid Society, is not available to the parents because Legal Aid regards itself as a single entity. The interest of the child and his parent may be in conflict, hence the Society cannot represent both. One cannot too strongly emphasize the need for lawyers in these cases. A neglect petition raises questions concerning the well-being and safety of a child, but it also raises questions respecting the happiness of respondent parents. In particular do parents need assistance in the great cities where there may be the sharpest differences between parents in the lower economic groups and the judge respecting a proper style of hife. The author has witnessed an exceedingly sharp tongue-lashing given by a family court judge of conservative leanings to a Negro mother for providing a "bad example" for her daughter. The mother was living with a man, not her husband, a situation which had endured for nine years. The girl's father had deserted her mother soine eleven years before, an event which the. state of New York did not recognize as a ground for divorce. The wonian was thunderstruck by the outburst and said nothing. The possible significance of the long, stable relationship and the reason for its irregnlar state were never presented to the judge. The judge might not have changed his mind, but certainly the wonian had not the advantage of soineone to speak for her and to explain the special circumstances of her case. She lacked an advocate, an advocate who conceivably could have prevented the loss of her child.

Free public counsel of the sort available in the juvenile court in New York is not readily available in the support parts of the Family Court. We need not again argue that an adversary procedure, set up to resolve situations of conflict, requires an advocate if the adversary procedure is to be successful.

\section{A Unified Family Court Fragmented}

The idea of a family court is born of the conviction that a single court ought to deal with the various problems of a single family, and of the behef that these problems require the assistance of well-trained experts for their resolution. An assault of a husband upon a wife, a running away by a child, the failure of a mother to prepare meals for her children all may be part of a single set of domestic problems. If the assailant is tried

28 See id. at 598 . 
in the criminal court, the runaway is the subject of a delinquency case, and the inother brought in on neglect allegations, the family's troubles will be approached pieceineal and not reviewed in one place-in a single court.

To carry out the "family court idea" the New York Family Court was given jurisdiction over family offenses-neglect, delinquency, support, filiation, termination of parental rights, and conciliation. ${ }^{29}$ The court is one and the power of the court is far-reaching, but the unity of the court has yielded to pressures for specialization and the realities of inadequate facilities.

While there are plans in New York City to erect a new family court building in Foley Square, the central location of the most important courts in Manhattan, at the moment the Family Court is scattered throughout the city. The Juvemile Term in Manhattan is separated, by many blocks, from the Support Term. In the four other boroughs these sections of the court ineet in the same place. However, the Family Offenses Term meets at 80 Lafayette Street, the City Wide Filiation Term meets at 52 Chambers Street, and the Adoption Term meets at 235 West 23rd Street. Thus a given family problem might require a good bit of travel from one part of a single court to another.

Specialization not only tends to deprive families of some of the benefits which a family court promises, but specialization may undermine the reputation of those who must use the court. As Judge Sylvia Jaffin Liese has observed: "Why should we have a separate court in which a woman who walks in is immediately identified as an unmarried mother?"30

\section{Disposition}

The catalogue of complaints regarding dispositions in juvenile courts runs from charges of abuse of discretion to an absence of the institutions which inight carry out wise judgments.

The fiexible powers of the juvenile court have been misused in the south in connection with civil rights demonstrations. ${ }^{31}$ The 1965 report of the U.S. Commission on Civil Rights reports that in Jackson, Mississippi, Americus, Georgia, and St. Augustine, Florida, juveniles who had been arrested in demonstrations "were threatened with imprisonment and, as a condition of exoneration or release, were forced to promise that they would not participate in future civil rights activities." 32

29 N.Y. FAanII Cr. ACT \& 115.

30 N.Y. Times, July 18, 1964, p. 24, col. 4.

31 U.S. Comou's on Civis Rights, Law Enforcentent, A Report on Equal Protectron IN THE SOUTH 80-83 (1965).

32 Id. at 80 . 
In Jackson, Mississippi, over one-half of the demonstrators arrested were juvemiles. Release of the children to their parents was conditioned on the parents doing everything possible to prevent further participation in demonstrations. ${ }^{33}$ In Americus, approximately 125 juveniles were arrested and about fifty were placed on probation on condition that they would not associate with certain civil rights leaders. ${ }^{34}$

Many juveniles in Americus were arrested for a long period of time and detained without bail or hearing. ${ }^{35}$ The report tells the story of a fourteen-year-old Negro girl who was charged with assault with intent to kill, unlawful assembly, rioting, and aiding an attempt to escape. Bail was set at 12,000 dollars. She spent eighty-seven days in jail without a hearing. ${ }^{36}$

In St. Augustine the juvenile court judge sent a letter to Negro leaders stating that parents ought not permit children to take part in demonstrations, after which juveniles in picket lines were removed by the police. Four youngsters who refused to promise that they would refrain from demonstration activity spent six months in the county jail and reform schools until they were released in January $1964 .^{37}$

In Maryland, juveniles who participated in a sit-in were conmitted to a state training school pending the hearing of an appeal from an adjudication of debinquency. ${ }^{38} \mathrm{An}$ appeal on this issue was unsuccessful because the Maryland High Court took the view that the trial court had not abused its discretion. ${ }^{39}$ It is pleasant to record that after another appeal the adjudications of delinquency were reversed. ${ }^{40}$ The adjudications, grounded on a "sit-in," and therefore an alleged criminal trespass, were held to be improper. Entering a theatre without tickets, lying on the theatre floor, and using profane language were, indeed, criminal activities; nevertheless, they were not a basis for a finding of dehinquency under the Maryland law. ${ }^{41}$ A determination of delinquency in Maryland requires an additional finding by the juvenile court judge that by reason of the offensive act the youngster is "in need of care or treatment . . . "42 The Maryland court said, "In the main the demonstrations in which they participated were conducted by adults who, although disorderly in many in-

33 Ibid.

34 Id. at 81 .

35 Ibid.

36 Id. at 82 .

37 Id. at $82-83$.

38 Ex parte Cromwell, 232 Md. 305, 192 A.2d 775 (1963).

39 Id. at 309,192 A.2d at 777.

40 In the Matter of Cromwell, 232 Md. 409, 194 A.2d 88 (1963).

41 Id. at 413, 194 A.2d at 90.

42 Ibid. 
stances, were not engaged in acts involving moral turpitude." ${ }^{33}$ The adult deinonstrators had either been required to pay minimum fines or the cases had been dismissed. "Incarceration of these children beyond the immediate need for their protection could hardly be supported." ${ }^{\prime 44}$

Two cases from New York evidence failure at the level of disposition. In one case a judge failed to inform himself properly, in the other the legislators failed to provide the facility necessary for sensible obedience to their own command. The young respondent in the first of the cases had been adjudicated a juvemile delinquent and placed in a New York State Agricultural and Industrial Training School. Four days after the factfinding hearing the juvenile had been brought, without his parents or the law guardian, before a judge of the Family Court in Buffalo, New York, for a dispositional hearing. The order committing him to the Training School, according to the Family Court Judge's notes, resulted from "written reports of no current investigation-see social history submitted in 1962"-nearly two years before the hearing. The disposition reached on the basis of this stale evidence was reversed; ${ }^{45}$ nevertheless, it is significant that it occurred at all. In an area of the law where so few appeals are taken, one is warranted in suspecting that discovered errors are but a sample of the practice in uncontested cases.

In the State of New York, the youngster who is not able to respond to adult authority is not classified as a delinquent but as a "person in need of supervision." A person in need of supervision (or PINS) may not be "committed" to a training school, but must be "placed" in a facility which is appropriate to a PINS.

The entire structure of the Family Court Act reflects a deliberate and calculated plan to place "persons in need of supervision" in authorized agencies for treatment and rehabilitation and not to commit them to penal institutions ....

The enlightened method of treatment of persons in need of supervision should be encouraged. ${ }^{46}$

A case styled In the Matter of Anonymous ${ }^{47}$ concerned a seventeenyear-old girl whose father had filed a petition alleging that she was a PINS, in that she kept late hours, lived in furnished rooms with two adult males, was suffering from syphilis for which she refused treatment, and refused to obey the lawful commands of her parents. There was no denial of the allegations.

\footnotetext{
43 Id. at 414,194 A.2d at 90 .

44 Ibid.

45 In the Matter of Smith, 21 App. Div. 2d 737, 249 N.Y.S.2d 395 (1964).

46 In the Matter of Anonymous, 43 Misc. 2d 213, 215, 250 N.Y.S.2d 395, 396 (Family Ct. 1964).

47 Supra note 46.
} 
For such a girl there are in the State of New York almost no facilities available. At that time, the state training schools could not be employed, ${ }^{48}$ and no other agency would take her. She had stayed in Youth House for Girls, a center for temporary detention, for a long time. Judge Polier relied upon a report finding that the girl had "deteriorated as a result of overlong remands to temporary detention." "49 The State Department of Social Welfare had refused to accept the girl in its facilities. No voluntary agency was available and further remand in the temporary detention home would have been unthinkable. Judge Polier sadly came to the conclusion that she had "no alternative but to release her to the home from which she caine." finds that the girl in this case must be paroled to her parents in the absence of any facility for her treatment and rehabilitation." 51 The legislature had failed to set up the kind of institution required by its own legislation.

Not only is there a lack of placement facilities in New York for PINS, but placement facilities for certain neglected children are almost nonexistent. It is especially difficult to place neglected children of Puerto Rican and Negro backgrounds, with the result that these cliildren are kept in temporary sleelters for very long periods of time. Judge Poher's study of the New York Family Court as of April 30, 1963, found that 14.5 per cent of the Negroes in temporary shelter care had been kept there for over one year. No white child had been in temporary care for such a long time. Only fourteen per cent of white children had been in temporary care for over five months. In contrast, Judge Polier reported, "39.5 per cent of the neglected Negro children and twenty-two per cent of the Puerto Rican children remained in the shelters for six months or more on repeated court remands pending court disposition." ${ }^{252}$ She affirmed that in New York there is only one significant shelter boarding home program for non-white neglected children involving long tern placement.

"Caseloads in the juvenile term now defy any possibility of probation work." 53 The Polier study discovered that forty-nine New York City juvenile probation officers were carrying caseloads ranging from 117 to 256 children. With such caseloads probation officers can only consult the

48 The New York legislature in 1965 amended the Family Court Act to allow placement of PINS in "authorized agencies," which includes state training schools. N.Y. FAMOIY Cr. ACr $\S 756$.

49 In the Matter of Anonymous, 43 Misc. 2d 213, 215, 250 N.Y.S.2d 395, 397 (Family

Ct. 1964).

50 Ibid.

51 Ibid.

52 PolIER, op. cit. supra note 17 , at 26.

${ }^{53} \mathrm{Id}$. at 44 . 
Social Service Exchange, get a formal report from school, and hold an office interview with the child and one parent. There can be no attempt to study the causes of family problems or to work out a sophisticated plan of treatment.

The probation staff in New York City is not very well-trained. Typically the New York probation officer assigned to work with juveniles has a college degree, but it may represent work in a field quite foreign to social work. The officer may or may not have taken a few professional courses. Usually he has become a probation officer after serving for a number of years as a social investigator in the Welfare Department, thus meeting the experience qualifications of the New York City civil service. Typically, a person on the probation staff with a Master's Degree in social work is a case supervisor and thus one step removed from first-hand contact with the youngsters supposedly to be benefitted by being in the charge of a tramed expert.

We perhaps need to be reminded about the shocking state of some of our institutions. A recent magazine article described the main characteristics of Junior Village, an institution for "dependent" or "neglected" children in Washington, D.C.54 The author asserts that the City of "Washington is running a great factory of retardation and mental ilhiess" because the Village is "too big, too crowded, and desperately understaffed, involuntarily inflicts severe-often permanent damage on small children."155

The crowded conditions of Junior Village reflect the fact that foster care is underdeveloped in the nation's capital. The number of homeless children has been rising, and the number of places to take care of then has not. The problen is particularly acute for Negroes; ninety-seven per cent of the children at Junior Village are Negroes. ${ }^{56}$

In the Village, mental retrogression occurs, it is charged, because the children are isolated "to a degree that would be impossible even in the most disorganized family." but fronl his brothers and sisters, because the institution segregates children by age and sex. The children are further separated from the adult world by the eight-hour shift. The author argues, "One counselor gets hin1 up in the morning, another puts him to bed at night, a third appears if he wakes in the night, and the following norning he sees a fourth face because the first counselor has a day off." $" 58$ The birthdays of children are celebrated collectively, one a month, with a communal birthday cake.

\footnotetext{
${ }^{54}$ Anderson, A Special Hell for Children in Washington, Harpers, Nov. 1965, p. 51.

$55 I d$. at 51-52.

$58 I d$. at 55.

57 Id. at 53.

58 Ibid.
} 
The damage to the children is often irreversible. Treatment in Junior Village leaves them impaired "in their ability to receive and return affection, to control their impulses, and to use their minds." Ironically, it is expensive in terms of public money as well as in terms of the waste of human resources to keep a child in an institution. A child costs 300 dollars a month at Junior Village, ${ }^{60}$ a handsome sum which few middle-class people are able to mount for their own children's needs.

\section{E. Morals versus Conciliation in Family Court}

Some of the poor do not share middle-class values about the regularity of family arrangements. "Common law" relationships often suffice. Whatever the economic or social position of the practice, a de facto family is much more important than a de jure relationship which no longer is maintained. Should minor assaults within a de facto family be transferred from a criminal court to a family court so that techniques of conciliation can be applied?

Under section 812 of the New York Family Court Act, transfers are to be made when the fighting occurs between spouses or "between members of the same household." This broad language led a District Judge in Nassau County to transfer an assault case to family court.

At first blush it would seem strange that a court whose purpose, in large part, is restoration and preservation of marriages, should concern itself with crimes between persons who are living in a meretricious relationship. From a strictly moral or even legal point of view, it is difficult to see why such a matter should be considered fit for the conciliatory and rehabilitative procedures of the Family Court.

Yet, if the jurisdiction were to be limited to legally constituted families, there was no need to add the word "or lousehold" to the statute. The legislature must be presumed to have been aware of a fact that is common knowledge to every law enforcement and social agency and to every court in this state, namely: there are countless houscholds where man and woman reside with their offspring in a domestic relationship on a permanent basis without being legally married. Such loouseholds are responsible for many of the most difficult social problems concerning such agencies on a daily, routine basis. They present behavior problems, support problems, mental and emotional problems. They concern the health, welfare and safety of children. They result in filiation proceedings, support proceedings and juvemile proceedings. In short, from a social point of view, this is a situation where the unique and flexible procedures and services available in the Family Court may possibly find a remedy. In some instances it may even be possible to arrange a legitimate marriage or at least furnish adequate counselling and protection.

59 Ibid.

$60 I d$. at 55 . 
It suffices to say that the relationship between this man and woman and the children residing with them is such as to constitute them a "household" as that term is generally used. They apparently eat, sleep and generally subsist as a single domestic unit depending on this defendant for support as its head. To hold otherwise from the mere fact that the man and woman are not legally married, would be to regard as meaningless surplusage the words "or household."

A contrary view was taken by a Dutchess County judge. The facts differed from those in the prior instance in that here the man and woman had not "held themselves out" as husband and wife. Nevertheless, the language of the opinion suggests that this distinction would not be controlling for the judge who decided the case.

It is the public policy of this State not to place children in a situation which would impair their morals. Even if the parties held themselves out to be man and wife under an alleged common law marriage, which is not the case here, this relationship would not change the moral atmosphere generated by these people living together under one roof.

Assuming this court accepted jurisdiction, the most that we could do in order to help would be to effect a marital reconciliation, which is inpossible in this situation. Actually, it would make the court a party, not only to an immoral relationship, but also, this court would be encouraging this relationship to continue.

The conciliation procedures cannot be utihzed in this situation for there is no marriage to begin with. ${ }^{62}$

Should middle-class morality stand in the way of extending conciliation attempts to those who might benefit from the help? Surely stateprovided conciliation procedures are appropriate to deal with domestic upheavals where children are involved in a de facto family of some permanence. Unless the community is prepared to remove the children of unmarried parents from the home, some effort should be made to make the environment physically and emotionally safe.

\section{V \\ THE CRISIS IN THE JUVENILE COURT}

The existence of a wide gap between the promise of the juvenile court and the reality has led to a sense of crisis among those working in the juvenile court field. Few today can regard a statement of Jane Addams' as anything but extraordinarily inaccurate in respect to the real situation obtaining in the juvenile courts of the United States:

There was almost a change in mores. when the juvenile court was established. The child was brought before the judge with no one to prosecute him and none to defend him-the judge and all concerned were

01 People v. Dugar, 37 Misc. 2d 652, 653-54, 235 N.Y.S.2d 152, 153-54 (Dist. Ct. 1962).

62 Best v. Macklin, 46 Misc. 2d 622, 623, 260 N.Y.S.2d 219, 221 (Family Ct. 1965). 
merely trying to find out what could be done on his behalf. The element of conflict was absolutely eliminated and with it all notions of punishment as such with its curiously belated connotations. ${ }^{.3}$

The reformers had a faith in the scientific skills of psychologists, psychiatrists, and social workers. A Children's Bureau publication of 1929 characterized the new court: "The old courts relied upon the learning of lawyers; the new courts depend more upon psychiatrists and social workers ... . Justice in the old courts was based on legal science; in the new courts it is based on social engingeering." author of perhaps the inost quoted statement about the task of the juvenile court: "The physical and mental condition of the child must be known ... therefore . . . every child, before hearing, shall be subject to a thoroughly scientific psycho-physical examination."05

The operation of the court was to be presided over by a inagistrate, educated, gifted, of almost saintly concern:

The position of judge of a family court requires qualities of the highest order; Broadmindedness, executive ability, tact, knowledge of the law, knowledge of the principles governing social work, and knowledge of people. To these must often be added the ability to convince appropriating authorities and the general public that sufficient funds must be made available. These specifications are rarely filled. ${ }^{00}$

What has happened to these dreams? On the twenty-first of March, 1966, Mr. Justice Fortas delivered the first opinion of the Supreme Court of the United States relating to the juvenile courts. His words were not reassuring:

While there can be no doubt of the original laudable purpose of juvemile courts, studies and critiques in recent years raise serious questions as to whether actual performance measures well enough against theoretical purpose to make tolerable the immunity of the process from the reach of constitutional guaranties applicable to adults. ${ }^{67}$

He went on to speak of the lack of

personnel, facilities and techniques to perform adequately as representatives of the state in a parens patriae capacity .... There is evidence, in fact, that there may be grounds for concern that the child receives the worst of both worlds: that he gets neither the protections accorded

03 Quoted in Rosenheim, Perennial Problems in the Juvenile Coutt, in JUSTICE FOR IERE CसmD 14 (Rosenheim ed. 1962).

64 U.S. Dep't of Labor, Chindren's Bureat, The ChmD, The Fanmty and the Court 21 (Pub. No. 193, 1929) (study by Flexner, Oppenheimer, and Lenroot).

65 Breckenrtige \& Abrott, The Detríquent Cand and the HoMre 199 (1912).

06 U.S. DEP'T OF LABOR, op. cit. supro note 64, at 36.

07 Kent v. United States, 86 Sup. Ct. 1045, 1054 (1966). 
to adults nor the solicitous care and regenerative treatment postulated for children. ${ }^{68}$

For the moment, at least, the Court did not insist on the full application of the Bill of Rights to juvenile cases; the lower court was reversed on the ground that the statutes applicable to the District of Columbia required the assistance of counsel at a hearing to determine whether a youngster should be transferred to the criminal court.

Mr. Justice Fortas wrote that some juvenile courts lack the persomel, facilities, and techniques to perform the parental tasks of government. Do any courts possess them? Can any courts which we are likely to see as existing institutions possess them?

Clearly, more resources more intelligently used can minimize some of the inconveniences and harms of the present system. Long-term, meaningless detentions in detention facilities can be avoided. Disposition of cases can be speeded up, educational opportunities can be extended. But what of the fundamental point of the reformers? Do we or could we have the tools for restructuring character by any program, however well-financed?

In 1920, a commentator observed that the juvenile court idea was designed to carry out "the duty of the state to give to the child who has made a slip another chance; to reclaim him, if possible, as a normal, useful member of society, and to shield him from the handicap and baneful atmosphere of criminal courts and jails." ${ }^{369}$ How much of the goal is attainable? To some extent, surely, we can "shield him" from the harms and horrors of the criminal jail and the accusing atmosphere of a criminal courtroom. The juvenile court can give the child "who has made a slip" a second chance. We can rely on the warning which a child might take from an appearance in court to educate him a bit. The court mechanisin gives us the means whereby the commumity can respond to a child's harmful conduct, can inform the youngster and other children that such conduct is not condoned, without at the same time taking harmful measures which might themselves create more trouble. The third task, the task to "reclaim him," is the troublesome one. We of course "reclaim" by giving a second chance and by preventing the harms the criminal law system can do, but can we in any other sense "reclaim" great numbers of children, and if so, by what techniques? The question and the challenge which we put to the reformers is precisely here. What are the means of change? Do they work? How expensive are they? How much is hope and how much is fact? The questions are put im no spirit of hostility. Those of us in the law who have

68 Ibid. (Emphasis added.)

${ }^{09}$ Towne, Shall the Age Jurisdiction of Juvenile Courts be Changed?, $10 \mathrm{~J}$. AMERTCAN InstTtute CrIM. L. AND CrRM. 493, 497 (1920). 
been concerned with juveniles and their court would like nothing better than to hear reassuring, affirmative answers.

Any answer which requires thousands of dollars of treatment for each offender of any serious degree is in practical effect a useless response. A recommendation of one hundred sessions of therapy does not give an item for mass production. We in 1966 seek with somewhat less assurance than in 1900 a hopeful answer to the question: What can the clinic do to change character? A useful answer will have to produce a correctional flivver-a useful, inexpensive, sturdy model (or line of models) which, because of its low cost, can be made available to all.

If we lack the means to perform miracles of liuman reclamation, should the juvenile court experinient be abandoned rather than merely modified by the introduction of more formal procedure derived from the criminal courts and by becoming somewhat less ready to undertake drastic intervention? In my view, such an abandonment would be quite wrong. An important reason wliy the juvenile court has survived is the grim prospect of the alternative. For example, in October 1965, a fourteen-year-old Colorado boy began serving a four to five year sentence in the state penitentiary on a rape charge growing out of an assault on a nime-year-old girl. ${ }^{70}$ The maximum penalty for the offense was five years. The judge could have sent the boy to a reforniatory where better facilities for rehabilitation were available. Nevertheless, the Colorado law permits the imposition of such severe punitive treatment. ${ }^{71}$

The young people who are brought to court, so many of them the children of the poor, would hardly benefit fronı being taken to a tribunal dealing with adult criminals. Juvenile courts, imperfect as they are, surely prevent some harm simply by doing less damage than the criminal courts would do to children in their middle teens. Acts done by teenagers may cause great damage, thus evoking cries of rage from the community. Often the juvenile courts, by an adjudication of delinquency, avoid harsh regimens of treatment. A great niany youthful offenses are not significant indices of bad eharacter. As to these, the juvenile court can reassure the community without destroying the life of the youngster by making an adjudication and thereafter leaving the youngster to treat himself. ${ }^{72}$

70 Denver Post, Oct. 13, 1965, p. 8.

71 See id., Editorial, Oct. 19, p. 20.

72 Cf. Note, Juvenile Delinquents: The Police, State Courts, and Individualized Justice, 79 HaRv. L. Rev. 775, 810 (1966): "If the system is maintained in the face of extremely limited treatment facilities and incompetent prediction methods, it might be well to establish a 'presumption' that a juvenile involved is more likely than not to reform himself as le matures. Considering the present number of police and intake 'settlements' and court 'continuances,' it may be said that such a 'presumption' is already in effect informally; but express recognition of the desirability of keeping the child out of treatment may bave a good deal of value." 